\title{
Causes and Impacts of Foreign Labour Migration on Household Economy
}

Mishra, Manamaya (M. Phil.)*

\begin{abstract}
This paper based on impact of foreign labour migration on household economy of Gauradaha municipality, ward no. 4 Jhapa district. The aims of this paper are to identify the causes and impacts of labor emigration in the place of their origin. It is a cross sectional and descriptive study with primary source of data. Study selected 132 household and 145 numbers of form fill up within one month and have used purposive sampling method (non-probability sampling). At last, SPSS (Statistical Package for the Social Sciences) program is used to compute the data. Frequency distribution, and cross table analysis are the main output of the analysis. The analysis has been done on the basis of data generated from the interview, the study has revealed unemployment, Poverty, lacks of opportunity in the home country is the reasons and obligations of labour migration. Gulf countries followed by East/South-East Asian countries have been the major destination of migrant workers. Due to the lack of higher education and proper training, they face problem in languages, skilled and are compelled to work as unskilled manual workers. Therefore, they have been working abroad in lower wage and salary due to the lesser skills. Bank and Hundi/IME are the major sources to transfer the remittances to their households. To buy essential goods and maintain the house expenses have been the first priorities of using the remittances. Besides, they have invested on education of their children and constructing houses.
\end{abstract}

Key words: Foreign labour migration, households, cause, impact \& change economy.

\section{Introduction}

International migration can be categorized into two groups as voluntary and forced migration. There has been a paradigm shift from traditional typologies of migration to voluntary, forced dichotomy which has emerged as commonly used distinction in recent studies on migration (Khatiwada, 2012). This study concerned with voluntary labor emigration in the study area. Labor migration is one of the integral parts of in

${ }^{*}$ Ms. Mishra is a Lecturer at the Department of Population Studies, Patan Multiple Campus, TU, Lalitpur, Nepal.Email: manishra4@gmail.com 
international migration. Labor emigration defined as movement of people across national boundaries to become involved in foreign employment. Flow of labor emigration from less developed countries to developed countries is increasing highly. There are various causes of international migration. Such as education, employment, professional work, visiting to relatives etc. are main causes of international migration. In the Nepalese context, migration for foreign employment has long been an important livelihood strategy for large part of rural areas. Most of Nepalese people migrated to the Gulf countries for employment. Huge volume of migrated population has illegal way for foreign employment. Visa is not needed for India. So, number and status of them has not accounted. Around 40 percent of migrants migrate to India and other 60 percent to the third countries (Khatiwada, 2012). National population census 2011 identified 19, 21,494 people are absent in the time of enumeration (CBS, 2014).

Most migrants originate worldwide from middle-income countries (157 million in 2015). Between 2000 and 2015, the number of migrants originating from middle-income countries increased more rapidly than those from countries in any other income group. The majority of migrants from middle-income countries were living in a high income country. The number of international migrants worldwide has continued to grow rapidly over the past fifteen years reaching 244 million in 2015, up from 222 million in 2010, 191 million in 2005 and 173 million in 2000. Between 2000 and 2005, the international migrant stock grew by an average of 2 per cent per year. During the period 2005-2010, the annual growth rate accelerated, reaching 3 per cent. Since then, however, it has slowed, falling to around 1.9 per cent per year during the period 2010-2015 (UN, 2016).

Globally, the raise in migration of workers across countries, the economic and social wellbeing of migrants, their families and their communities has been increasing. Growth in the number of international migrants has been robust over the last two decades, reaching 281 million people living outside their country of origin in 2020, up from 173 million in 2000 and 221 million in 2010. Currently, international migrants represent about 3.6 per cent of the world's population (UNDESA, 2020).

This is the fact that remittance has larger benefit to the receiving country in an aggregate level as well as in household level. The volume of remittance inflow in study areas is increasing day by day and season by season. While the remittance income of households increase certainly the pattern of consumption will change remittance has helped to boost education, reduce poverty provided temporary financial relief to household in study area. 
The majority of remittance and migration literature available focus on the transnational population movements. The economic and social impacts on the area of origin and destination due to flow of human resource is less understood and studied as compared to goods and capital flows among the countries in the era of globalization. The detailed studies on remittances are encountered by controversies. First, whether or not migration and remittances decisions are separable or not is not clear. When a migrant does not send money in the form of remittances, the economic effect of remittance to the place of origin becomes non-measurable. Second, whether or not the remittance income is different to any other source of income or not is subject to debate (Pyakurel, 2018). If remittance income is different to other sources of income for the household, how and why it is different but it is different to the financial or capital flows in the international level as the remittance income receipts are the households and the capital flow receipts are the businesses or the government. So, remittances will have direct impact on the household level (Pyakurel, 2018).

This paper plays a significant role in the sense that it will provide insight in understanding the issue of Nepalese international labour migration particularly includes Gauradaha municipality in Jhapa district. Several studies have been name concerning labour migration is other parts but highest in Jhapa. So, it is purely concern with Gauradaha municipality in Jhapa district. Its aim is to study the labour migration in the study area with special attention to livelihood strategies. It is crucial to know what motives people from this study will not however, limit to only the study area. This paper try to fulfill the research questions:-What are the main causes of labour migration and its impact on household economy?

\section{Objectives}

- To describe the causes of international labour migration.

- To find out the use of remittances in different sectors of the households.

\section{Method}

This paper is based on descriptive and exploratory research design. It assumed the descriptive method too because it attempt to describe situation of study site and the impact of remittance on household economy. Primary as well as secondary data are used in the paper. As per the need of the study, primary and secondary data are collected. Mix data (qualitative and quantitative data) are used in this paper. Primary data or the first hand data are collected via the field study adopting various participatory means via household 
survey, interview and focus group discussion. The total numbers of international labour migrant's households of the study area are 567. Study selected 132 respondents of these total households of form fill up within one month and have used purposive sampling method (non- probability sampling). At last, SPSS (Statistical Package for the Social Sciences) program is used to compute the data. Frequency distribution, and cross table analysis are the main output of the analysis.

\section{Limitations}

This paper generalized to curtained extent only i.e. Jhapa district. It covered only Gauradaha municipality. Ward number 4 which is the one of the limitation. The foreign migrant families HH 132 selected as the respondents. The interview mainly focused on socio-economic status and the changes seen in their households.

\section{Results and Discussion}

\section{Income Status and Ownership of Land}

In total households, 27 percent labour migrants have below than Rs. 50,000 income per year. The highest i.e. 55.3 percent labour migrants income level in between Rs. 1,00,000 $-1,50,000,10.6$ percent labour migrants have level of income is in 2,00,000 and above annual income, and 6.8 percent respondents have income level is in between 1,00,000 $2,00,000$ thousand. This study found that the level of income was not good of study area. The highest 22.7 percent of the households have 21-30 katthas. Likewise, 18.9 percent have 11-20 katthas where as 11.4 percent of the households have 31-40 katthas. The households with no land consist only 14 percent.

\section{Causes of Migration}

The large group of unemployment and lack of opportunities are the major focal point for most of the labour migrants. Reasons of migrating for 44.8 percent labour migrants were unemployment. During the interview with the returnees and migrant households, they state that opportunity of employment is extremely limited in the country, which have compelled them to go abroad for foreign employment. About one half of the males and more than one-fourth of the females expressed that unemployment is the main cause behind the labour migration. 
Table 1: Distribution of respondents by causes of foreign labour migration.

\begin{tabular}{|l|c|c|}
\hline Reasons & Number & Percent \\
\hline Unemployment & 60 & 44.8 \\
\hline Poverty & 21 & 17.9 \\
\hline Lack of opportunity & 23 & 16.6 \\
\hline Indebtedness & 24 & 17.9 \\
\hline Less inclination on agriculture & 4 & 2.8 \\
\hline Total & $\mathbf{1 3 2}$ & $\mathbf{1 0 0 . 0}$ \\
\hline
\end{tabular}

Source: Field Survey, 2020.

\section{Destination of Migration}

The destination of the foreign migrants is confined to five gulf countries like Kuwait, Oman, Qatar, Saudi-Arab, United Arab Emirats (UAE) followed by eight Asian countries which include Israel, Iraq, Japan, Malaysia, South Korea, Singapore, Afghanistan and Hong Kong. Highest percentages of migrants (47.7\%) have their destination to gulf countries followed by Malaysia (21.9\%) of the total migrants.

\section{Remittance and Influences on Household Economy}

Majority of the migrants (62.1\%) send their remittances through bank. Among the total migrants 34.5 percent send their remittance through Hundi/IME. The other important system of remittance is friends/Colleague which is only 3.4 percent of the total migrants send their remittance through their closely friends and colleague. In this remitting system their friend and colleagues help them to carry the remittances to Nepal.

\section{Income of Foreign Migrants}

During the focus group discussion with political workers, social workers, some students and some housewives and interview with the returnees and the migrant households, people saying that most of the Nepali migrant workers get up to Rs. 20,000/- per month in Malaysia and Gulf countries. The migrants getting the monthly salary more than Rs.20,000/- to Rs.30,000/- per months are in few numbers in Malaysia and Gulf countries. The migrants getting the monthly salary more than Rs. 20,000/- in these countries are those who have worked there for a long period of time and who have satisfied the employer of the company. Similarly, Nepalese migrant workers get Rs.30,000/- to Rs.40,000/- and Rs.40,000/- to Rs.50,000/- in Israel, Afghanistan and Iraq who have not provided the 
work permit but reached there through illegal channels and in the Gulf countries for those only who are skilled and have got job in the renowned and reputed companies.

Table 2: Distribution of respondents by monthly income

\begin{tabular}{|l|c|c|}
\hline Monthly Salary (in 000 Rs) & Number & Percent \\
\hline$<20$ & 33 & 25.0 \\
\hline $20-30$ & 56 & 42.4 \\
\hline $30-40$ & 12 & 9.1 \\
\hline $40-50$ & 10 & 7.6 \\
\hline $50-60$ & 8 & 6.1 \\
\hline $60-70$ & 7 & 5.3 \\
\hline 70 and above & 6 & 4.5 \\
\hline Total & $\mathbf{1 3 2}$ & $\mathbf{1 0 0 . 0}$ \\
\hline
\end{tabular}

Source: Field Survey, 2020.

One-fourth percent of foreign labour migrants received their salaries less than Rs. 20, 000/- per month. During the interview, people shared that most of the female migrants are uneducated, unskilled or semi- skilled, inability and thus are working as domestic helpers or households workers abroad. Likewise, the highest i.e. 42.3 percent of the total migrants get salaries between Rs.20,000/- to Rs.30,000/- which is followed by 9.1 percent of the migrants getting salaries between Rs.30,000/- to Rs.40,000/-. Similarly, 7.6 percent of the total migrants get salaries between Rs.40,000/- to Rs.50,000/- which is followed by 4.5 percent of the migrants getting salaries between Rs.70,000/- and above.

Table 3: Distribution of respondents by amount of remittances received

\begin{tabular}{|l|c|c|}
\hline Amount of Income (in 000Rs) & Number & Percent \\
\hline$<100$ & 20 & 15.2 \\
\hline $100-400$ & 60 & 45.6 \\
\hline $400-700$ & 18 & 13.6 \\
\hline $700-1000$ & 11 & 8.3 \\
\hline $1000-1300$ & 4 & 3.0 \\
\hline $1300-1600$ & 3 & 2.3 \\
\hline 1600 and above & 7 & 5.5 \\
\hline Not stated & 9 & 6.8 \\
\hline Total & $\mathbf{1 3 2}$ & $\mathbf{1 0 0 . 0}$ \\
\hline
\end{tabular}

Source: Field Survey, 2020. 
More than 45 percent of the total migrant workers of the study area have the level of income between Rs. 100, 000/- to Rs. 4,00,000/-. Likewise, 15.2 percent of the total migrants have the level of income below Rs. 1, 00,000/-. These are the migrants who have just gone abroad or have returned in a short period of time or are provided with very low salaries. During the interview with the returnees and migrant households people said that as majority of the Nepalese migrant laborers have gone to the Gulf and Malaysia, they get poor salaries than others and it directly affects their income. For example, a migrant laborer who works in Malaysia for two years earns not more than Rs. 2,00,000/- to Rs. $3,00,000 /-$ after subtracting the invested amount but if they find the overtime facilities they earn a little bit more than that income. Among the total migrants 13.6 percent have the level of income between Rs.4,00,000/- to Rs. 7,00,000/- respectively.

\section{Use of Remittances}

During the focus group discussion and interview, people expressed that most of the households give the first priority to cover the basic needs and house expenses. Some of them who have large remittances invest on the small business or lend money to other an invest buy land construct the houses, invest in the children's higher education or buy cattle or invest on productive works, which further become the extra sources of income. But in case of most of families, the remittance is just enough to cover their basic essential needs.

Table 4: Migrants households by use of remittances

\begin{tabular}{|l|c|c|}
\hline Remittance used Areas & Number & Percent \\
\hline Buying land & 67 & 50.8 \\
\hline House build & 71 & 53.8 \\
\hline Education & 73 & 55.3 \\
\hline Health & 74 & 56.1 \\
\hline Buying foods clothes & 81 & 61.4 \\
\hline Payment of debt & 82 & 62.1 \\
\hline Saving/providing loan & 27 & 20.5 \\
\hline Marriage/buying vehicles & 22 & 16.7 \\
\hline
\end{tabular}

Source: Field Survey, 2020.

Note: Percent total may exceed 100 due to multiple responses.

Among 132 households, 82 households responded that they used some amount of their remittances to pay their debt. Similarly, most of households of foreign migrants have 
used the remittance to meet the daily essential things and expenses like food, clothing, education and health. Majority of the households numbering 81 among 132 households expressed their views that they have used some amount of the remittances for buying food and clothes, 73, 74 households each for children's education and children's health purpose respectively. Likewise, 71 households stated that they have used the remittances for building a new house while 67 households expressed that they have invested the remittances for buying land. Only 27 households stated that they have their deposited the money in the banks or have provided loads to other. Few households numbering 22 stated other reasons for using the remittances with include buying vehicles, investing on cultivation productive works and business and for marriage purposes.

\section{Impact of Migration}

All of these aspects have been examined in the study area, 64 percent of the respondents had expressed their attitudes about the influences of migration while 36 percent did not respond or they were reluctant to express. During the interview with returnees and migrant households and focus group discussion with political workers, social workers, students and housewives, people expressing their views about the influences of migration expressed that foreign employment has been the main reason behind improvement in the economic condition of the households. People of the study area have positive attitude towards foreign employment from the view point of employment and livelihood. Likewise, the other positive impacts are inflow of remittance from foreign countries, knowledge and commands on various skills to know about custom, traditional culture, language, lifestyle and economic and social development, they have been able to spend or donate a small amount for the social activities in the study area. It has been taken as positive impact.

The negative impact of foreign employment has been on agriculture, shortage of labour, increasing dependency of that whole family over the earning of a member from foreign labour migration for their households expenses. The family has to manage for necessary expenses in order to send the family member for foreign labour migration. They have to borrow money with very high interest rate with the hope that within few years time the loan will be paid back with interest from the earning from foreign employment. In certain cases the result become disastrous due to various unforeseen incidents reasons and the family will have to repay the loan by selling their land and other properties. Many people expressed that other impact is the cheating done by the broker and the manpower agencies. In the place of work they are not provided the amount of salary to cover required cheating by the broker and such cheating has ruined the economic condition of the people who want to go abroad. The broker demands them pre- payment while going abroad and 
cheats the whole amount as well. Such cheating by the broker has ruined some people of the study area.

Table 5: Migrants' households with Different facilities (before and after) the labour migration

\begin{tabular}{|l|c|c|c|c|c|c|c|c|c|c|}
\hline \multirow{3}{*}{ Household Particulars } & \multicolumn{4}{|c|}{ Before } & \multicolumn{4}{c|}{ After } & \multicolumn{2}{c|}{ Total } \\
\cline { 2 - 12 } & \multicolumn{2}{|c|}{ Yes } & \multicolumn{2}{c|}{ No } & \multicolumn{2}{c|}{ Yes } & \multicolumn{2}{c|}{ No } & \multicolumn{2}{c|}{} \\
\cline { 2 - 12 } & No. & \% & No. & \% & No. & \% & No. & \% & No. & \% \\
\hline Gas, stove & 60 & 45.5 & 72 & 54.5 & 99 & 75 & 33 & 25.0 & 132 & 100.0 \\
\hline TV, Radio, sound system & 57 & 43.2 & 75 & 56.8 & 69 & 52.3 & 63 & 47.7 & 123 & 100.0 \\
\hline Vehicle (motorbike, car, bus) & 6 & 4.5 & 126 & 95.5 & 21 & 15.9 & 111 & 84.1 & 132 & 100.0 \\
\hline
\end{tabular}

Source: Field survey, 2020.

There is a huge fluctuation in the household particulars in the study area, before going to foreign employment and after going to foreign employment. The households who did not have furniture were 70.5 percent before but it came down 13.6 percent after going to foreign employment. Similarly, 54.5 percent of the households who did not have gas, stove before were reduced to 25.0 percent. Similarly, the households with essential, expensive and luxurious materials like TV, Radio, sound system with only 43.2 percent before was lifted up to 52.3 percent after going to foreign employment. The percent of the households with vehicles was only 4.5 percent before which increased to 15.9 percent after going to foreign employment.

\section{Transforming Economic Environment of the Household}

During the time of the focus group discussion with the political workers, social workers, students and housewives, people expressed that all members of family have their own responsibility in each household. Everyone's responsibility may not bear by other so all the members should come on general understanding to run a house with good environment. If the head of a family leaves the house for long period, then other member should have a capacity of running the house weak or wisely as well as the house members condition is very poor and badness. But money is not only a solution of running a family. The entire member should work together and cooperate with each other in the matters related with the household and it members. According to field study, it has found that the most of the housewives of migrant workers may feel lonely and marry due to their long absence; a lot of the wives of migrant workers are less educated. Therefore, they are disappointed and distressed even by a simple problem. They can't evaluate which is right is or which is 
wrong they can't decision their children's progress in their studies or can't keep track of the children's activities and as a result some of the children might not be going to school and might get involved in bad habit of gambling, drug addiction, theft and another.

\section{Changing Households' Assets}

During the time period of the focus group discussion with the political workers, social workers, students and housewives and interview with the returnees and migrant households, people expressed migration has resulted in the possession of the assets of the households in the study area. It has changed culturalization. Socialization, living standard lifestyle and other household in my study area. Income from foreign employment has improved condition of house of many households as well as improvement of the individual members in education, behavior, and food and dresses habit.

In the focus group discussion and interview, people shared that consequently, migrant household are constructing the houses build of brick and cement and concrete instead of other. Their houses are equipped with modern equipment, accessories and other luxurious goods. Because of the facilities of electricity many of the households of migrants have been able to use television, radio, Refrigerator, electric heater, electric iron as well as the rice cooker in their kitchen. Due to the good income, varieties of food and have been included in their cuisine. Most of the households cook foods on the biogas, gas stove instead of firewood because of the easy availability of cooking gas cylinder in the market. They have also brought enough ornaments Jewelery and gold. The numbers of the rich family have brought private motor vehicle and motorbike.

During the focus group discussion, people expressed that as the foreign labour migrants are not able to cultivate their agriculture land they let the landless and other poor communities cultivate their land as share or upper of tenant farmer. The landless and poor people have been able to own land as share cropper or tenant farmer and have been able to improve their livelihood. Most of luxurious goods are available in their home. The living standard of the household for the study area has changed. But the labour migration has not improved economic condition of all households in my study area. It has also some ruined some households which were expressed during the time period of focus group discussion with political workers, social workers, students and housewives and interview with the returnees and migrant households. 


\section{Conclusion}

The main causes of international labour migration is lack of employment opportunity and desired types of works in the place of origin forces the people to seek other sources of income. In this study area the majority of international labour migration is found as to seek better income in cities, job seeking on forced idleness during the part of year and services. They are compelled to send their husbands and sons to gulf countries to earn something to maintain subsistence of the households. Despite their poverty and have workloads the women are very much aware of improving their economic status and natural environment that is the conservation of the forest on community basis. The study area are not interested in getting higher level of education because they feel that with higher education, they will have the difficulty in getting government services which have characterized corruption like nepotism, Favoritism and briberies to secure jobs. Some seven youth who passed the S.L.C.(School Leaving Certificate) examination went to Gulf countries as labour migrants instead of pursing for higher education staying in the village as unemployment at present subjected to be involuntary recruited by the political in its people war group or harassment by the security forces of as unrest wars of political situation. Unproductive utilization of labour uncontrolled outflow of labour, low paid work and illegal transfer, employment discrimination in respect to color, age, sex, ethnicity, religion and others are major problems being faced by migrant workers. Therefore, it is urgent necessity for the developed as well as developing countries to solve these problems, which only possible through the ratification of the present convention.

\section{Acknowledgements}

I would like to thanks Gauradaha municipality, ward no. 4 office to support financially and social for conducting household survey of foreign labour migrant's household. I am always thankful for all respondents who are support this survey for giving their valuable time at the period of COVID-19 pandemic.

\section{References}

Central Bureau of Statistics (CBS). (2014). Population monograph of Nepal. Kathmandu: National Planning Commission Secretariat, Central Bureau of Statistics, Government of Nepal, Nepal.

Ministry of Labour and Employment (MoLE). (2016/2017). Labour migration for employment: A status report for Nepal: 2016/2017. Kathmandu, Government of Nepal. 
Ministry of Labour and Employment (MoLE). (2013/2014). Labour migration for employment: A status report for Nepal: 2013/2014. Kathmandu, Government of Nepal.

Khatiwada, P. P. (2012). Cause and consequences of international migration in Nepal. An unpublished dissertation submitted to Central Department of Population Studies (CDPS), Kathmandu, Nepal.

Pyakurel, U. P. (2018). Restrictive labour migration policy on Nepalese women and consequences. Sociology and Anthropology, 6(8). DOI: 10.13189/sa.2018.060803.

National Human Rights Commission (NHRC). (2008/09). National report: Trafficking in person especially on women and children in Nepal. Harihar Bhawan, Pulchock, Lalitpur, Nepal.

United Nations (UN). (2016). International migration report, (Geneva: UN)

United Nations Department of Economic and Social Affairs (UNDESA). (2020). International migration 2020 highlights. United Nation Organization, New York. 